\title{
УДОСКОНАЛЕННЯ ЕКСТРЕНОЇ МЕДИЧНОЇ ДОПОМОГИ ВІДПОВІДНО ДО МЕДИЧНОЇ РЕФОРМИ НА РІЗНИХ ЕТАПАХ ЇЇ НАДАННЯ
}

\author{
T. B. Koca \\ Комунальне некомериійне підприємство «Територіальне медичне об’єднання \\ "Обласний центр екстреної медичної допомоги та медищини катастроф" \\ Запорізької обласної ради \\ Тернопільський національний медичний університет \\ імені І. Я. Горбачевського МОЗ Украӥни
}

У статті висвітлено потребу врегулювання організації та функціонування служби екстреної медичної допомоги на різних рівнях догоспітального етапу.

\section{IMPROVEMENT OF EMERGENCY MEDICAL CARE ACCORDING TO THE HEALTH CARE REFORM ON DIFFERENT STAGES}

\author{
T. V. Kosa \\ Regional non-profit enterprise "Territorial Medical Association" Regional Center of \\ Emergency Medical Care and Disaster Medicine”, Zaporizhzhia Regional Council \\ I. Horbachevsky Ternopil National Medical University
}

The article describes the need for regulation of the organization and functioning of emergency medical service at different levels of the pre-hospital phase.

Вступ. Наприкінці 2018 р. в Україні стартувала медична реформа. Трансформацію системи охорони здоров'я спланували провести в три етапи:

1. Реформування закладів первинної ланки.

2. Реформування закладів вторинної та третинної допомоги.

3. Впровадження професійного ліцензування лікарів.

Дайджест змін у медичному законодавстві 2019 р. Мета медичної реформи - трансформувати сферу охорони здоров'я, щоб: зробити якісні медичні послуги і ліки доступними, поліпшити ефективність використання бюджетних коштів, долучити місцеве самоврядування до розвитку медичної галузі, підвищити рівень задоволеності населення системою охорони здоров'я, зміцнити здоров'я та подовжити тривалість життя громадян.

Як наслідок, від змін, передбачених медичною реформою, мають виграти всі: пацієнти, які отримуватимуть якісні й доступні медичні послуги; медичні працівники, умови роботи й зарплата яких поліп-

(c) T. B. Koca, 2020 шаться; медичні заклади, які вільно використовуватимуть кошти, враховуючи нагальні потреби лікувального закладу.

Фахівці, які трансформують медичну сферу, називають модель реформування медицини в 2020 р. еволюційною і підкреслюють, що реформа відбуватиметься 3-4 роки, а то й довше.

у 2016 р. уряд ухвалив Концепцію реформи фінансування системи охорони здоров'я. Відтак МОЗ почало розробляти план заходів щодо ії реалізації. З того часу ухвалили та оновили чимало нормативних документів, які регламентують функціонування нової моделі медичної допомоги. Головний документ, що стосується медичної реформи, - Закон України «Про державні фінансові гарантії медичного обслуговування населення» від 19.10.2017 р. № 2168-VIII - набрав чинності 30 січня 2018 р. Відповідно до плану реформування медичної галузі, наприкінці грудня 2017 р. створили Національну службу здоров'я України (НСЗУ) як основний орган, що реформує систему фінансування охорони здоров'я. НСЗУ - центральний орган виконавчої влади, що реалізує державну політику в сфері 
державних фінансових гарантій медичного обслуговування населення за Програмою медичних гарантій. Завдання НСЗУ - закупівля якісних медичних послуг для пацієнтів та контроль за ефективним витрачанням бюджетних коштів у межах Програми медичних гарантій (ПМГ). Уже на початку функціонування НСЗУ їі партнерами стали як комунальні заклади охорони здоров'я, так і приватні клініки та лікарі-ФОПи.

\section{Етапи медичної реформи: 2018-2020 рр.}

2018 р. - початок реформування первинної ланки медичної допомоги: заклади первинки трансформувалися в комунальні некомерційні підприємства (КНП), підписали перші договори з НСЗУ, а пацієнти уклали декларації про вибір лікаря; затвердження першої Програми медичних гарантій для первинної медичної допомоги; запровадження електронної системи охорони здоров'я eHealth - скоротилася кількість паперових документів; уся інформація про пацієнта знаходиться в одному місці; знизився ризик втрати медичних даних пацієнта.

2019 р. - реімбурсація лікарських засобів через НСЗУ: урядова програма «Доступні ліки» дає змогу пацієнтам із серцево-судинними захворюваннями, бронхіальною астмою, цукровим діабетом II типу отримувати препарати безплатно чи з незначною доплатою; зміна підходу до закупівлі ліків; підготовка до запуску Програми медичних гарантій в 2020 р.; ухвалення Програми медичних гарантій; ухвалення Держбюджету на 2020 р., в якому визначено видатки на ПМг; запровадження пільгового періоду щодо реорганізації медичних закладів із бюджетних установ у КНП, що передбачає спрощену процедуру реорганізації до 31.12.2020 р.

Основна частина. Запорізька область має велику протяжність території, розгалужену мережу населених пунктів та всього п'ять територіальних округів та декілька лікарень, які можуть приймати хворих та постраждалих цілодобово. При цьому виникають певні незручності доїзду пацієнтів до вузькопрофільних спеціалістів. А стан наших доріг не дає можливості бригадам екстреної медичної допомоги швидко та без перешкод доставляти хворих до лікувальних закладів, вкладаючись в так зване «терапевтичне вікно», при інсультах, гострому коронарному синдромі, інфаркті міокарда чи політравмі.

У місті Запоріжжя працює оперативно-диспетчерське управління на базі Комунального некомерційного підприємства «Територіальне медичне об'єднання «Обласний центр екстреної медичної допомоги та медицини катастроф» Запорізької обласної ради, яке приймає виклики від громадян та від працівників медичних закладів за телефонною лінією «103». Потім фельдшер із медицини невідкладних станів 3 приймання викликів та передачі їх виїзним бригадам швидкої медичної допомоги (ШМД) передає виклик в електронному вигляді на смартфон або планшет виїзним бригадам ШМД, що значно скорочує час прийняття виклику та його передачу, це суттєво впливає на доїзд бригади до місця виклику. За статистичними даними, доїзд бригад екстреної (швидкої) медичної допомоги у містах області складає 89 \% до 10 хв, а в сільській місцевості - 88 \% до 20 хв.

Реформування системи охорони здоров'я в Україні за сучасних умов $є$ реальною необхідністю. Стара радянська модель функціонування цієї системи не відповідає вимогам сьогодення, адже давно країна живе за ринковими відносинами, і лише медична галузь залишилася осторонь. Як результат - «хронічне» недофінансування, розпорошення матеріальних та кадрових ресурсів, нераціональне використання навіть того, що виділяють.

Шанси на те, що у разі настання нещасного випадку чи серцевого нападу життя людини буде врятовано, а негативні наслідки для здоров'я - мінімізовані, залежать від строку початку надання першої допомоги та строку початку проведення критичних для виживання процедур на догоспітальному етапі, які повинні бути мінімальними. Не менше значення має ефективне госпітальне лікування та реабілітація. Кожна з перелічених ланок в Україні організована неефективно.

Перша проблема - недосконала організація раннього доступу до надання першої допомоги [4].

Згідно з доказовими дослідженнями, статистично значуще зростання показників виживання серед пацієнтів екстреної медичної допомоги досягається лише у разі, коли пацієнти можуть розраховувати на початок такої допомоги не пізніше ніж через 4 хв після настання екстреної ситуації. Настільки ранній доступ можливий лише у разі надання ефективної першої допомоги та забезпечення базової підтримки життя безпосередніми свідками на місці події. Хоча такі особи не можуть замінити професійних медичних працівників, вони можуть допомогти підтримати життя до прибуття професіоналів.

В Україні навички першої допомоги формально $\epsilon$ частиною підготовки деяких фахівців (рятувальників аварійно-рятувальних служб, поліцейських тощо). 
Проте поточний підхід до їх залучення не є ефективним через ряд причин:

- не існує ефективного механізму контролю якості знань за результатами освітніх заходів;

- не існує реєстру осіб, які пройшли тренінги 3 надання першої допомоги, та відсутній механізм оперативного залучення їх до надання першої допомоги у разі настання нещасного випадку або надзвичайної ситуації;

- добровольці, які наважуються рятувати людину до прибуття швидкої, ніяк не захищені законодавством від притягнення до відповідальності у разі, коли людині все-таки не вдасться зберегти життя.

Друга проблема - недостатня швидкість прибуття бригад екстреної (швидкої) медичної допомоги на місце події [4].

Однією з найбільш обговорюваних проблем $\epsilon$ незадовільний стан доріг загального користування та місцевих доріг. Більшість людей переконана, що від стану дорожньої інфраструктури залежить не лише подальший розвиток країни, але й безпека кожного громадянина. Відсутність вуличного освітлення, назв вулиць та нумерації будинків у вечірні години доби затримує час прибуття бригади екстреної медичної допомоги.

Значна кількість громадян України, а саме особи з вадами зору та слуху, - сьогодні взагалі практично позбавлені шансу викликати екстрену медичну допомогу, оскільки такий виклик може прийматися лише через телефонний дзвінок.

Третя, найбільша, проблема - незадовільна якість надання медичної допомоги на догоспітальному етапі [4].

На сьогодні в Україні можливості бригад екстреної (швидкої) медичної допомоги (більшість з яких є фельдшерськими, тобто складається з фельдшера, водія і, іноді, медсестри) надавати екстрену медичну допомогу високої якості є вкрай обмеженими, оскільки:

- професійна підготовка лікарів, фельдшерів здійснюється за стандартним принципом підготовки медичних працівників без достатнього врахування особливостей роботи вумовах надзвичайної ситуації;

- незважаючи на присутність у складі таких бригад інших працівників, зазначені члени бригад екстреної (швидкої) медичної допомоги не мають достатньої підготовки, щоб надати таку допомогу ефективно в проведенні реанімаційних заходів; крім того, участь у наданні екстреної медичної допомоги не входить у функціональні обов'язки водія бригади екстреної (швидкої) медичної допомоги.

Професійна підготовка, кваліфікаційні вимоги та організація діяльності медичних працівників системи екстреної медичної допомоги не включає навичок роботи в команді. Водночас саме ефективна командна робота $є$ запорукою якісної медичної допомоги пацієнту, який перебуває у невідкладному стані. Результати досліджень свідчать, що часто причиною смерті або ускладненого перебігу захворювання пацієнтів, які перебувають у невідкладному стані, $\epsilon$ не лише індивідуальні помилки окремих медичних працівників, але і неефективність координації командної роботи фахівців бригади екстреної (швидкої) медичної допомоги або працівників відділення екстреної (невідкладної) медичної допомоги закладу охорони здоров'я.

Низький рівень набутих навичок медичних працівників системи екстреної медичної допомоги зумовлений як відсутністю ефективних принципів підготовки фахівців, так і відсутністю ефективної системи контролю якості знань. Індивідуальна оцінка готовності лікарів до виконання своїх обов'язків сьогодні обмежується системою атестації та переатестації для підтвердження або підвищення кваліфікації. Цей підхід має ряд недоліків, а саме:

- формальний характер, відсутність нагляду за якістю курсів підвищення кваліфікації та незалежного оцінювання для перевірки їх результатів, що створює корупційні ризики (адже якість навчання перевіряє та ж організація, що проводить це навчання);

- відсутність засвоєння та відновлення практичних навичок під час підвищення кваліфікації;

- застарілі програми, далекі від щоденної практики бригади екстреної (швидкої) медичної допомоги;

- відсутність ефективного механізму нагляду за проведенням передатестаційних циклів;

- відсутність дієвого механізму офіційного визнання міжнародних курсів, які проходять працівники системи екстреної медичної допомоги, як курсів, що зараховуються під час підвищення кваліфікації, що демотивує працівників опановувати доказові міжнародні практики.

Окремою додатковою проблемою $\epsilon$ відсутність в Україні національних галузевих стандартів у сфері охорони здоров'я з надання екстреної медичної допомоги, що ґрунтуються на доказовій медицині. Наявні галузеві стандарти є застарілими і часто суперечать 
доказовим міжнародним практикам. Також відсутній і механізм нагляду за дотриманням галузевих стандартів у сфері охорони здоров'я з надання екстреної медичної допомоги медичними працівниками.

Четверта проблема - незадовільна якість та швидкість надання екстреної медичної допомоги на госпітальному етапі [4].

Шанси пацієнта не лише своєчасно потрапити в лікарню, але і бути успішно пролікованим, прямо залежать від підходів до організації надання екстреної медичної допомоги на госпітальному етапі. Ймовірність летального випадку, в тому числі через додаткові ускладнення, сьогодні збільшують такі чинники:

- невідповідність сучасним вимогам надання екстреної медичної допомоги у відділеннях екстреної (невідкладної) медичної допомоги закладів охорони здоров'я, що приймають пацієнтів;

- неспроможність більшості закладів охорони здоров'я, куди доставляють пацієнтів, провести повноцінну діагностику і надати комплексну медичну допомогу хворому, який перебуває у невідкладному стані;

- транспортування хворих, які перебувають у невідкладному стані, за територіальним принципом;

- відсутність чітких моделей комунікації та координації між бригадою екстреної (швидкої) медичної допомоги та відділенням екстреної (невідкладної) медичної допомоги;

- відсутність чітких моделей координації між відділеннями лікарні під час роботи зі складними невідкладними випадками.

Крім безпосереднього впливу на перебіг захворювання та невідкладного стану пацієнта, нескоординовані процеси на рівні лікарні призводять до неефективного використання ліжкового фонду та робочого часу медичних працівників.

П'ята проблема - низька спроможність системи екстреної медичної допомоги своєчасно забезпечити достатній об'єм якісної медичної допомоги у разі виникнення надзвичайних ситуацій та ліквідації їх наслідків [5].

Наявні в Україні алгоритми реагування на надзвичайні ситуації (в тому числі - плани реагування державного, регіонального рівнів та плани реагування на рівні закладів охорони здоров'я) мають ряд прогалин.

Поточні плани реагування не відстежують і не враховують реальну інформацію про здатність закладів охорони здоров'я швидко збільшити кількість лікарняних ліжок та кількість пацієнтів, які отримують екстрену медичну допомогу на госпітальному етапі.
Така здатність включає не лише наявність місця для розміщення пацієнтів, але і необхідне технічне оснащення для одночасного надання екстреної медичної допомоги значній кількості осіб. Не сформована дієва система резервування медикаментів, медичних виробів.

Механізм міжвідомчої координації та взаємодії під час реагування на масові випадки, в тому числі на догоспітальному етапі, також $\epsilon$ мало дієвим.

Найважливішими елементами системи, яка включає засоби, процеси, заходи, які залучаються до ліквідації наслідків надзвичайних ситуацій, - оперативно-диспетчерські служби - не обладнані автономним радіозв'язком, що повинен об'єднувати всі наявні бригади екстреної (швидкої) медичної допомоги, підрозділи екстреної медичної допомоги та заклади охорони здоров'я.

Не існує системи безперервного професійного розвитку, в тому числі практичних тренінгів щодо дій у разі виникнення інцидентів з великою кількістю постраждалих, із кризового менеджменту для працівників закладів охорони здоров'я, які працюють в режимі надання екстреної медичної допомоги.

Крім того, діюча система реагування не містить системної вимоги до регулярного вдосконалення підходів шляхом аналізу досвіду реагування на надзвичайні події, що уже відбулись, а також обов'язкових періодичних тренувань, в тому числі зі залученням громадськості.

Ми на порозі страхової медицини, тому страхові компанії чітко обраховуватимуть вартість кожної медичної послуги та неухильно слідкуватимуть за виконанням протоколів надання ЕМД. Екстрена медична допомога на догоспітальному етапі, як і вся медична допомога взагалі, за сучасних умов вимагає стандартизації, тобто встановлення вимог і рекомендацій для того, щоб досягти найвищої якості медичної допомоги - належного (відповідно до стандартів, клінічних протоколів) проведення всіх заходів, що $\epsilon$ безпечними, раціональними, прийнятними з точки зору коштів, які використовуються в даному суспільстві, і впливають на смертність, захворюваність, інвалідність. За статистичними даними, в Україні збільшується питома вага фельдшерських бригад, які обслуговують понад 80 \% населення України.

І ще одне. Більшість «фельдшерських» бригад у районах складається лише з самого фельдшера та водія, якого не залучають до надання екстреної медичної допомоги. Як можна виконати усі дії за про- 
токолом, коли реально для надання допомоги $є$ лише одна пара рук? Неможливо самотужки правильно перекласти постраждалого. А якщо їх декілька і допомоги більше немає? А як бути у випадку інфаркту міокарда з кардіогенним шоком, коли потрібно вводити декілька медичних препаратів, які не можна змішувати? Про які стандарти надання медичної допомоги, про яку якість можна говорити?

Сучасний підхід до кадрового забезпечення системи екстреної медичної допомоги потребує удосконалення. Зокрема, повинно бути чітко визначено склад загальнопрофільних або спеціалізованих бригад. А це, відповідно, потребує введення змін та доповнень до кваліфікаційних вимог спеціалістів та фахівців, які працюватимуть у складі цих бригад. Важливою $\epsilon$ участь водія санітарного автотранспорту в наданні медичної допомоги на догоспітальному етапі у складі єдиної бригади, а для цього необхідно провести підготовку та навчання водіїв з питань надання першої медичної допомоги, визначити обсяг їх обов'язків та затвердити посаду водій-парамедик.

Із досвіду роботи з аналогічними службами у Польщі можна сказати, що за кордоном цю проблему намагаються вирішити, складаючи бригади з двох медичних працівників або парамедиків, які мають право на керування каретою швидкої медичної допомоги. У Польщі поряд із парамедиками залишаються реанімаційні й інші спеціалізовані лікарські бригади. У Німеччині в особливих випадках на допомогу бригаді парамедиків виїжджає лікар. При цьому він може виїхати легковим автомобілем, знаючи, що все необхідне медичне обладнання $\epsilon$ у кареті швидкої допомоги, включаючи дихальну апаратуру, кардіомонітор, набори для реанімації тощо. А що говорити про обладнання наших машин швидкої медичної допомоги? Спільною із європейськими машинами $є$ лише назва.

Висновки. Варто зазначити, що в Євросоюзі до надання медичної допомоги на догоспітальному етапі залучаються медичні та немедичні працівники, суворо регламентований об'єм надання медичної допомоги кожного з них та чітко визначені стандарти медичної допомоги. Тож ситуацію в Україні потрібно кардинально змінювати.

У питанні щодо скорочення закладів та штатів Служби екстреної медичної допомоги, функціонування єдиних загальнопрофільних бригад (лікарськихабо фельдшерських) чи спеціалізованих бригад потрібно підходити професійно, з урахуванням специфіки кожної області, населення та потреби у наданні допомоги, статистичних показників роботи служб. Необхідно ознайомитися та вивчити досвід країн Європейської Співдружності щодо їхньої організації аналогічних служб та адаптувати це до умов роботи в Україні.

Однією зі складових системи екстреної медичної допомоги є медицина катастроф. У Постанові Кабінету Міністрів України від 11 липня 2001 р. за № 827 «Про затвердження Положення про Державну службу медицини катастроф» сказано (дослівно):

- п. 1. Державна служба медицини катастроф (далі - Служба) є особливим видом державної аварійно-рятувальної служби, основним завданням якої $є$ надання безоплатної медичної допомоги постраждалим від надзвичайних ситуацій техногенного та природного характеру (далі - надзвичайні ситуації), рятувальникам та особам, які беруть участь у ліквідації наслідків надзвичайних ситуацій.

- п. 10. Особовий склад (медичні та інші працівники) медичних формувань Служби повинен мати відповідний рівень підготовки для надання екстреної медичної допомоги у разі виникнення надзвичайних ситуацій і бути здатним за станом здоров'я виконувати роботи в екстремальних умовах. Усі медичні формування та їхній особовий склад підлягають обов'язковій атестації. Порядок атестації медичних формувань, їхнього особового складу визначається МОЗ України. Атестовані медичні формування заносяться до спеціального реєстру аварійно-рятувальних служб. На атестований особовий склад медичних формувань, занесених до реєстру, поширюються положення про права, обов'язки, гарантії соціального захисту та відповідальність рятувальників згідно з Законом України «Про аварійно-рятувальні служби».

З 2001 р. і до сьогодні не внесено жодних змін у правові та нормативні акти щодо підготовки фахівців ДСМК. Працівники центрів медицини катастроф офіційно не мають статусу рятувальника і відповідного соціального захисту, як це прописано у чинному законодавстві України. Хоча у своїй роботі вони надають екстрену медичну допомогу постраждалим у надзвичайних ситуаціях, а виконання цієї роботи може призвести до небезпеки чи загрози життю, погіршення здоров'я членів бригад медицини катастроф. Ще один аспект: для надання допомоги при ліквідації наслідків надзвичайної ситуації залучають бригади швидкої медичної допомоги як бригади постійної готовності 1-ї черги. Але чинним законодавством і для них також не передбачено статусу рятувальників. 
Екстрена медична допомога має бути такою, щоб забезпечити доїзд відповідних бригад до пацієнтів у межах 10 хв у містах та 20 хв у сільській місцевості згідно з наказом МОЗ України від 01.06.2009 р. № 370 «Про єдину систему надання екстреної медичної допомоги». Але враховуючи такі фактори сьогодення, як віддаленість розташування баз швидкої та невідкладної медичної допомоги від місця виклику, географічний фактор, застарілу матеріальнотехнічну базу мережі швидкої та невідкладної медичної допомоги, особливо у сільській місцевості, невпорядкованість руху автомобільного транспорту, низький рівень культури водіїв на автошляхах, чи можна виконати нормативи доїзду?

I, нарешті, як резюме. Не менш важливою проблемою служб догоспітального етапу $\epsilon$ відсутність у них менеджменту, свого інституту екстреної медичної допомоги, в якому були б об'єднані як практичні установи системи ЕМД, так і кафедри навчальних установ різних рівнів акредитації.

На сьогодні в Законі України «Про екстрену медичну допомогу» $\epsilon$ термін «домедична допомога». Це поняття $\epsilon$ недосконалим. Незважаючи на відсутність медичної освіти у надавачів першої допомоги, їхні дії спрямовані на порятунок життя людини і не можуть протиставлятися медичній допомозі. Крім того, дії осіб, які зобов'язані до цього законом та службовими обов'язками, щодо надання першої допомоги не можуть обмежуватись.

У світовій практиці, зокрема у рекомендаціях Всесвітньої організації охорони здоров'я, рівні медичної допомоги визначаються відповідно до медичних завдань, на які вони спрямовані, а також відповідно до кваліфікації надавачів. Уживану в Україні термінологію необхідно вдосконалити для відповідності таким міжнародно визнаним підходам.

Зокрема, потрібно розрізняти такі етапи надання допомоги людині, яка перебуває у невідкладному стані, залежно від суб'єктів надання такої допомоги:

- перша базова допомога, яка спрямована на забезпечення базової підтримки життя; суб'єктами, які надають таку допомогу, $є$ особи, які першими з'явилися на місці події;

- перша розширена допомога, яка спрямована на забезпечення базової підтримки життя, але припускає більший об'єм володіння необхідними навичками, у тому числі навичками роботи зі спеціальним обладнанням; суб'єктами, які надають таку допомогу, $\epsilon$ особи, які не мають медичної освіти, але за своїми службовими обов'язками повинні володіти основними практичними навичками з рятування та збереження життя людини, яка перебуває у невідкладному стані, та відповідно до закону зобов'язані здійснювати такі дії та заходи;

- догоспітальна базова допомога - допомога на догоспітальному етапі, яка надається відповідно до медичних настанов для подальшої підтримки циркуляції, відновлення прохідності дихальних шляхів та адекватної вентиляції до прибуття пацієнта в заклад охорони здоров'я для отримання госпітальної допомоги; суб'єктами, які надають таку допомогу, $\epsilon$ екстрені медичні техніки, які не $\epsilon$ медичними працівниками, мають відповідну підготовку та працюють у складі бригади екстреної (швидкої) медичної допомоги;

- догоспітальна розширена допомога - професійні дії на догоспітальному етапі відповідно до медичних настанов для подальшої підтримки циркуляції, відновлення прохідності дихальних шляхів та адекватної вентиляції до прибуття пацієнта в заклад охорони здоров'я для отримання госпітальної допомоги; суб'єктами, які надають таку допомогу, є медичні працівники бригади екстреної (швидкої) медичної допомоги;

- госпітальна екстрена медична допомога передбачає надання екстреної медичної допомоги на госпітальному етапі у відділеннях екстреної (невідкладної) медичної допомоги; суб'єктами, які надають таку допомогу, є медичні працівники відділень екстреної (невідкладної) медичної допомоги закладів охорони здоров'я;

- госпітальна спеціалізована допомога, яка надається у спеціалізованих відділеннях закладів охорони здоров'я; суб'єктами, які надають таку допомогу, $€$ медичні працівники відповідних відділень.

Крім того, необхідно запровадити більш системний підхід до організації першої допомоги.

На сьогодні в Україні зусилля, спрямовані на забезпечення надання першої допомоги постраждалим в екстрених ситуаціях, є фрагментованими, позбавленими загальної організаційної мети, цільової методологічної та інформаційної підтримки. Для стійкого покращення ефективності цих зусиль вони повинні бути організовані як взаємозв'язана система. Системна співпраця органів державної влади та органів місцевого самоврядування, урядових та неурядових установ та організацій і громадян із метою посилення якості першої допомоги буде спрямована на виконання таких завдань: 
- обов'язкове оволодіння навичками першої допомоги та відповідну сертифікацію працівників, чия діяльність пов'язана з високою ймовірністю присутності в екстрених ситуаціях і входить до їхніх обов'язків згідно із законодавством, створення і ведення реєстру таких осіб, забезпечення проведення регулярних навчань для підтримки навичок та продовження дії сертифіката, перевірок на володіння відповідними компетентностями;

- підтримка можливостей проходження бажаючими громадянами за власні кошти навчання з отриманням сертифіката екстреного медичного реагувальника або оволодіння загальними навичками першої допомоги без отримання такого сертифіката;

- започаткування проведення постійної просвітницької роботи серед населення, в тому числі поширення інформації про перші кроки для свідків невідкладного стану, із залученням органів місцевого самоврядування, каналів поширення масової інформації, громадських організацій;

- розширення доступу до якісного стандартизованого оволодіння навичками першої допомоги дітям

\section{СПИСОК ЛІТЕРАТУРИ}

1. Власні дослідження.

2. Про затвердження Положення про Державну службу медицини катастроф : Постанова Кабінету Міністрів України від 11 липня 2001 р. № 827.

3. Про єдину систему надання екстреної медичної допомоги : наказ МОЗ України від 01.06.2009 р. № 370. для батьків під час вагітності та в післяпологовий період;

- залучення благодійних організацій та приватних підприємств на засадах корпоративної соціальної відповідальності до фінансової підтримки оснащення засобами першої допомоги місць високої ймовірності екстрених ситуацій з потребою у наданні першої допомоги постраждалим (зокрема - великих станцій громадського транспорту), розроблення інтерактивних карт та програмного забезпечення (прикладних програм для мобільних засобів комунікації) для ідентифікації розміщення найближчого оснащення першої допомоги, зокрема дефібриляторів;

- захист надавачів першої допомоги від судових переслідувань зі сторони постраждалого або його законних представників у разі, коли вони допустили помилку під час добровільного надання першої допомоги такій особі або їхні зусилля виявилися неефективними (в тому числі за допомогою правового регулювання, відомого в світі як «закон доброго самаритянина»).

4. Про схвалення Концепції розвитку системи екстреної медичної допомоги : розпорядження Кабінету Міністрів України від 22 травня 2019 р. № 383-р [Електронний ресурс]. - Режим доступу : https://zakon.rada.gov.ua/laws/ show/383-2019-\%D1\%80. 